\title{
HUBUNGAN INDEKS MASSA TUBUH DAN RIWAYAT KELUARGA DENGAN KEJADIAN DIABETES MELLITUS TIPE 2 DI DAERAH PESISIR KOTA KENDARI
}

\author{
Tien*, Musyarrafah**, Andi Noor Kholidha***, Pranita Aritrina****, \\ Ikhlasul Amal Abdal*****, Arimaswati****** \\ *Fakultas Kedokteran Universitas Halu Oleo, Kendari, Sulawesi Tenggara \\ **Fakultas Kedokteran Universitas Islam Al-Azhar, Mataram, Nusa Tenggara Barat \\ ***Program Studi Pendidikan Dokter, Fakultas Kedokteran Halu Oleo, Kendari, Sulawesi \\ Tenggara
}

\begin{abstract}
Background: Diabetes Mellitus is a metabolic disease characterized by chronic hiperglikemia and caused by the impairment of insulin secretion or insulin resistance or both. There are some risk factors in the process. They are obesity, lack of activity, nutritional deficiency, family history of diabetes, history of gestational diabetes, old age, and genetic.

Research Purpose: This research purpose is to understand the relationship between risk factors including obesity and family history with the incident of type-2 DM in coastal area of Kendari.

Research Methods: This research used analytical-observational study with case control approach. The independent variables used in this research are Body Mass Index (BMI) and family history while the the dependent variables are the incident of type-2 DM. The location of this research is working area of Puskesmas Mata, Puskesmas Benu-benua, Puskesmas Kandai, Puskesmas Abeli and Puskesmas Poasia located in the coastal area. There are 75 people choosen to be our samples by include and exclude criteria with cluster sampling method. Data are obtained by using questionnaire and laboratory analysis. The results are processed by applying Chi-Square test with $\mathrm{p}<0,050$ and the Odd Ratio score.

Research Result: This research showed that between BMI with the incident of type-2 DM has $\mathrm{p}=0,000(\mathrm{OR}=7,875)$, between family history with the incident of type- $2 \mathrm{DM}$ has $\mathrm{p}=0,030$ $(\mathrm{OR}=2,800)$, between $\mathrm{BMI}$ and family history with the incident of type-2 DM has $\mathrm{p}=0,000$ $(\mathrm{OR}=14,571)$.Conclusion: The conclusion of this research was that the relationship between BMI with the incident of type-2 DM in the coastal area of Kendari exists. The relationship between family history with the incident of type-2 DM in the coastal area of Kendari exists. The relationship between BMI and family history with the incident of type-2 DM in the coastal area of Kendari exists.
\end{abstract}

Keywords: Body Mass Index, Family History, Diabetes Mellitus, Coastal Area.

\section{PENDAHULUAN}

Diabetes Melitus (DM) adalah suatu kelompok penyakit kompleks dan heterogen, ditandai oleh berkurangnya kadar insulin yang diproduksi oleh sel beta pada pankreas (Kommoju, 2011). Sementara itu, menurut World Health Organization (WHO) (2006), mendeskrip-sikan DM sebagai suatu gangguan metabolik yang etiologinya yaitu, hiperglikemia kronik dengan gangguan metabolisme karbohidrat, lemak dan protein yang dihasilkan dari kegagalan sekresi insulin, kerja insulin maupun keduanya. Terdapat beberapa tipe dari diabetes melitus, tetapi ada 2 tipe yang umum pada masyarakat yaitu diabetes melitus tipe 1 dan diabetes melitus tipe 2 (DM tipe-2). Diabetes Melitus tipe-2 ini memiliki jumlah penderita lebih dari $90 \%$ dari kasus diabetes (ADA, 2014).

Diabetes Melitus pun menjadi masalah kesehatan di seluruh dunia 
karena prevalensinya yang cukup tinggi.

Data dari International Diabetes Federation (IDF), penderita DM di dunia pada tahun 2015 mencapai 415 juta orang atau sekitar $8,8 \%$ dari jumlah penduduk dunia. Hasil Riset Kesehatan Dasar (Rikesdas) sebagaimana dipublikasikan oleh Kementerian Kesehatan menunjukkan bahwa persentase penderita DM tipe-2 pada tahun 2013 sekitar 1,5\% dari jumlah penduduk Indonesia. Untuk wilayah Sulawesi Tenggara $1,1 \%$ dari jumlah penduduk Sulawesi Tenggara, sedangkan menurut data dari Dinas Kesehatan Sulawesi Tenggara (2015), sekitar 3206 orang atau $0,12 \%$ dari jumlah penduduk di Sulawesi Tengggara menderita penyakit DM. Data dari Dinas Kesehatan Kota Kendari (2015), sekitar 955 orang atau $0,27 \%$ dari jumlah penduduk menderita DM.

Beberapa faktor risiko menjadi penyebab terjadinya DM tipe-2, dibagi menjadi 2 yaitu, dapat diubah (obesitas, kurang beraktifitas, nutrisi yang buruk, hipertensi, dislipidemia dan merokok) dan tidak dapat diubah (riwayat keluarga diabetes, riwayat diabetes gestasional, umur tua, dan genetik). Menurut Trisnawati (2013), faktor risiko utama untuk DM tipe-2 adalah obesitas yang hubungannya dengan DM tipe-2 sangatlah kompleks. Obesitas dapat menyebakan resisten insulin sehingga kadar gula di dalam darah juga dapat mengalami gangguan (Guyton, 2008). Pengukuran yang dapat dilakukan untuk mengetahui tingkat obesitas adalah Indeks Massa Tubuh (IMT) yaitu perbandingan berat badan (dalam kilogram) dengan kuadrat tinggi badan (dalam meter) (Justitia, 2012). Pengukuran IMT yang dilakukan berkaian erat dengan terjadinya intoleransi glukosa pada masyarakat pedesaan maupun perkotaan (Trisnawati, 2009).

Penelitian yang dilakukan oleh Kekenusa dkk, (2014) menyebutkan bahwa riwayat keluarga yang menderita DM termasuk dalam faktor tidak dapat diubah dan memiliki hubungan yang erat dengan kejadian DM Tipe 2, sehingga dengan mengetahui faktor ini, individu yang berisiko menderita DM Tipe 2 dapat melakukan pencegahan dengan mengendalikan faktor lain yang berhubungan dengan kejadian DM Tipe 2.

Oleh karena itu, peneliti dalam kajian ini memilih DM tipe-2 sebagai objek kajian karena mengingat semakin tinggi dan meningkatnya angka prevalensi DM tipe-2 di Indonesia termasuk Sulawesi Tenggara yang sebagian besar wilayahnya merupakan wilayah pesisir. Hal ini membuat peneliti menjadi tertarik untuk melakukan penelitian hubungan indeks massa tubuh dan riwayat keluarga dengan kejadian DM tipe-2 di daerah pesisir Kota Kendari dengan harapan dapat bermanfaat dalam mengetahui 
faktor risiko dan sebagai informasi dalam pemilihan obat yang tepat pada pengobatan DM tipe-2.

\section{METODE PENELITIAN}

Jenis dari penelitian ini adalah analitik observasional dengan pendekatan case control. Penelitian ini dilaksanakan pada bulan November sampai dengan Desember 2016 di daerah pesisir Kota Kendari. Teknik pengamblan sampel dalam penelitian ini adalah cluster sampling dengan total sampel dalam penelitian ini adalah 75 orang yang terdiri dari 39 orang sampel kasus dan 36 orang sampel kontrol.

Pengumpulan data primer dilakukan dengan memberikan kuesioner, peme-riksaan IMT, dan pemeriksaan GDP kepada sampel penelitian. Analisis data dilakukan dengan menggunakan uji statistic Chi-Square, dengan nilai $\mathrm{p}<0,05$ dan Odd Ratio dengan bantuan IBM SPSS Statistics 22. Penelitian ini telah mendapatkan perse-tujuan dari Komisi Etik Penelitian Kesehatan Lembaga Penelitian dan Pengabdian pada Masyarakat Universitas Halu Oleo.

\section{HASIL}

\section{Karakteristik Sampel Penelitian}

Berdasarkan Tabel 1.1, Penelitian ini menggunakan jumlah sampel sebanyak 75 orang, terdapat 39 orang sebagai sampel kasus dan 36 orang sebagai sampel kontrol. Terdapat 54 orang $(72,0 \%)$ dengan usia $\geq 45$ tahun, jumlah sampel kasus sebanyak 34 orang $(87,2 \%)$ dan kontrol sebanyak 20 orang $(55,6 \%)$. Usia $<45$ tahun berjumlah 21 orang $(28,0 \%)$ dengan sampel kasus sebanyak 5 orang $(12,8 \%)$ dan kontrol 16 orang (44,4\%). Distribusi sampel berdasarkan karakteristik jenis kelamin, terdapat 17 orang $(22,7 \%)$ dengan jenis kelamin laki-laki, jumlah sampel kasus sebanyak 9 orang $(23,1 \%)$ dan kontrol sebanyak 8 orang $(22,2 \%)$. Jenis kelamin perempuan berjumlah 58 orang $(77,3 \%)$ dengan sampel kasus sebanyak 30 orang $(76,9 \%)$ dan kontrol sebanyak 28 orang (77,8\%). Distribusi sampel berdasarkan karakteristik kadar GDP, terdapat 29 orang (38,7\%) dengan kadar GDP $\geq 126$ mg/dl, jumlah sampel kasus sebanyak 29 orang $(74,4 \%)$ dan kontrol tidak ada. Untuk kadar GDP <126 mg/dl sebanyak 46 orang $(61,3 \%)$, jumlah sampel kasus sebanyak 10 orang $(25,6 \%)$ dan kontrol sebanyak 36 orang (100\%). 
Tabel 1.1 Distribusi Sampel Berdasarkan Karakteristik.

\begin{tabular}{|c|c|c|c|c|c|c|}
\hline \multirow{3}{*}{ Karakteristik } & \multicolumn{4}{|c|}{ Kejadian DM } & \multirow{2}{*}{\multicolumn{2}{|c|}{ Total }} \\
\hline & \multicolumn{2}{|c|}{ Kasus } & \multicolumn{2}{|c|}{ Kontrol } & & \\
\hline & $\mathbf{N}$ & $\%$ & $\mathbf{N}$ & $\%$ & $\mathbf{N}$ & $\%$ \\
\hline \multicolumn{7}{|l|}{ Umur } \\
\hline$\geq 45$ tahun & 34 & 87,2 & 20 & 55,6 & 54 & 72,0 \\
\hline$<45$ tahun & 5 & 12,8 & 16 & 44,4 & 21 & 28,0 \\
\hline \multicolumn{7}{|l|}{ Jenis Kelamin } \\
\hline Laki-laki & 9 & 23,1 & 8 & 22,2 & 17 & 22,7 \\
\hline Perempuan & 30 & 76,9 & 28 & 77,8 & 58 & 77,3 \\
\hline \multicolumn{7}{|l|}{ Kadar GDP } \\
\hline$\geq 126 \mathrm{mg} / \mathrm{dl}$ & 29 & 74,4 & 0 & 0,0 & 29 & 38,7 \\
\hline$<126 \mathrm{mg} / \mathrm{dl}$ & 10 & 25,6 & 36 & 100,0 & 46 & 61,3 \\
\hline Jumlah & 39 & 100 & 36 & 100 & 75 & 100 \\
\hline
\end{tabular}

\section{Analisis Bivariat}

\section{a. Hubungan IMT dengan kejadian DM Tipe-2 di daerah pesisir Kota} Kendari

Berdasarkan Tabel 1.2, menunjukkan bahwa jumlah sampel kasus yang memiliki IMT lebih sebanyak 27 orang $(69,2 \%)$ dan normal sebanyak 12 orang (30,8\%). Jumlah sampel kontrol yang memiliki IMT lebih sebanyak 8 orang $(22,2 \%)$ dan normal sebanyak 28 orang $(77,8 \%)$.

Hasil uji Chi-Square dalam penelitian ini menunjukkan bahwa terdapat hubungan antara IMT dengan kejadian DM tipe-2 di daerah pesisir Kota Kendari, dengan nilai $p=0,000$. Nilai OR dari data sampel diperoleh sebesar 7,875 yang memiliki arti bahwa orang dengan IMT lebih memiliki risiko 7,875 kali lebih besar menderita penyakit DM Tipe2 dibandingkan dengan orang yang memiliki IMT normal.

\section{b. Hubungan riwayat keluarga dengan kejadian DM tipe-2 di daerah pesisir Kota Kendari}

Berdasarkan Tabel 1.3, menujukkan bahwa jumlah sampel kasus yang memiliki riwayat keluarga sebanyak 26 orang $(66,7 \%)$ dan tidak memiliki riwayat sebanyak 13 orang $(33,3 \%)$. Jumlah sampel kontrol yang memiliki riwayat keluarga sebanyak 15 orang $(41,7 \%)$ dan tidak memiliki riwayat sebanyak 21 orang $(58,3 \%)$.

Hasil pengolahan data yang dilakukan menujukkan bahwa terdapat hubungan antara riwayat keluarga dengan kejadian DM tipe-2 di daerah pesisir Kota Kendari, dilihat dari perolehan hasil uji Chi-Square yang dilakukan dengan nilai $\mathrm{p}=0.0300$. Nilai OR dari penelitian ini sebesar 2,800 yang memiliki arti bahwa orang dengan riwayat keluarga DM tipe-2 memiliki risiko 2,8 kali lebih besar menderita penyakit DM tipe-2 dibandingkan dengan orang yang tidak memiliki riwayat keluarga. 
Tabel 1.2 Hubungan IMT dengan kejadian DM Tipe-2 di daerah pesisir Kota Kendari.

\begin{tabular}{|c|c|c|c|c|c|c|c|c|}
\hline & \multicolumn{4}{|c|}{ Kategori Sampel } & \multirow{2}{*}{\multicolumn{2}{|c|}{ Total }} & \multirow{3}{*}{$X^{2}$} & \multirow{3}{*}{ OR } \\
\hline & \multicolumn{2}{|c|}{ Kasus } & \multicolumn{2}{|c|}{ Kontrol } & & & & \\
\hline & $\mathbf{N}$ & $\%$ & $\mathbf{N}$ & $\%$ & $\mathbf{N}$ & $\%$ & & \\
\hline \multicolumn{9}{|l|}{ IMT } \\
\hline Lebih & 27 & 69,2 & 8 & 22,2 & 35 & 46,7 & \multirow{2}{*}{0,000} & \multirow{2}{*}{7,875} \\
\hline Normal & 12 & 30,8 & 28 & 77,8 & 40 & 53,3 & & \\
\hline Jumlah & 39 & 100,0 & 36 & 100,0 & 75 & 100,0 & & \\
\hline
\end{tabular}

Tabel 1.3 Hubungan riwayat keluarga dengan kejadian DM Tipe-2 di daerah pesisir Kota Kendari.

\begin{tabular}{|c|c|c|c|c|c|c|c|c|}
\hline & \multicolumn{4}{|c|}{ Kategori Sampel } & \multirow{2}{*}{\multicolumn{2}{|c|}{ Total }} & \multirow{3}{*}{$X^{2}$} & \multirow{3}{*}{ OR } \\
\hline & \multicolumn{2}{|c|}{ Kasus } & \multicolumn{2}{|c|}{ Kontrol } & & & & \\
\hline & $\mathbf{N}$ & $\%$ & $\mathbf{N}$ & $\%$ & $\mathbf{N}$ & $\%$ & & \\
\hline \multicolumn{9}{|l|}{$\begin{array}{l}\text { Riwayat } \\
\text { Keluarga }\end{array}$} \\
\hline $\mathbf{Y a}$ & 26 & 66,7 & 15 & 41,7 & 41 & 54,7 & \multirow{2}{*}{0,0300} & \multirow{2}{*}{2,800} \\
\hline Tidak & 13 & 33,3 & 21 & 58,3 & 34 & 45,3 & & \\
\hline Jumlah & 39 & 100,0 & 36 & 100,0 & 75 & 100,0 & & \\
\hline
\end{tabular}

\section{c. Hubunngan IMT dan riwayat} keluarga dengan kejadian DM tipe-

\section{2 di daerah pesisir Kota Kendari}

Berdasarkan Tabel 1.4, menujukkan bahwa jumlah sampel yang memiliki IMT lebih dan riwayat keluarga DM tipe-2 sebanyak 18 orang $(46,2 \%)$ untuk sampel kasus dan 2 orang $(5,6 \%)$ untuk sampel kontrol. Sedangkan, yang tidak sebanyak 21 orang $(53,8 \%)$ untuk sampel kasus dan 34 orang $(94,4 \%)$ untuk sampel kontrol.

Hasil pengolahan data yang dilakukan menujukkan bahwa terdapat hubungan antara IMT dan riwayat keluarga dengan kejadian DM tipe-2 di daerah pesisir Kota Kendari, dilihat dari perolehan hasil uji Chi-Square yang dilakukan dengan nilai $\mathrm{p}=0.000$. Nilai OR dari penelitian ini sebesar 14,571 yang memiliki arti bahwa orang dengan IMT lebih dan riwayat keluarga DM tipe-2 memiliki risiko 14,571 kali lebih besar menderita penyakit DM tipe-2 dibandingkan dengan orang yang tidak memiliki riwayat keluarga DM tipe-2.

\section{PEMBAHASAN}

a. Hubungan IMT dengan kejadian DM tipe-2 di daerah pesisir Kota Kendari

Hasil pengolahan data dengan menggunakan uji Chi-Square dalam penelitian ini menunjukkan bahwa terdapat hubungan antara IMT dengan kejadian DM tipe-2 di daerah pesisir Kota Kendari, dilihat dari perolehan nilai $\mathrm{p}=0,000$. Nilai OR dari data sampel 
diperoleh sebesar 7,875 yang memiliki

menderita penyakit

DM tipe-2

arti bahwa orang dengan IMT lebih dibandingkan dengan orang yang memiliki risiko 7,875 kali lebih besar memiliki IMT normal.

Tabel 1.4 Hubungan IMT dan riwayat keluarga dengan kejadian DM tipe-2 di daerah pesisir Kota Kendari.

\begin{tabular}{|c|c|c|c|c|c|c|c|c|}
\hline & \multicolumn{4}{|c|}{ Kategori Sampel } & \multirow{2}{*}{\multicolumn{2}{|c|}{ Total }} & \multirow{3}{*}{$X^{2}$} & \multirow{3}{*}{$\mathbf{O R}$} \\
\hline & \multicolumn{2}{|c|}{ Kasus } & \multicolumn{2}{|c|}{ Kontrol } & & & & \\
\hline & $\mathbf{N}$ & $\%$ & $\mathbf{N}$ & $\%$ & $\mathbf{N}$ & $\%$ & & \\
\hline \multirow{3}{*}{\multicolumn{9}{|c|}{$\begin{array}{l}\text { IMT dan } \\
\text { Riwayat } \\
\text { Keluarga }\end{array}$}} \\
\hline & & & & & & & & \\
\hline & & & & & & & & \\
\hline $\mathbf{Y a}$ & 18 & 46,2 & 2 & 5,6 & 20 & 26,7 & \multirow{2}{*}{0,000} & \multirow{2}{*}{14,571} \\
\hline Tidak & 21 & 53,8 & 34 & 94,4 & 55 & 73,3 & & \\
\hline Jumlah & 39 & 100 & 36 & 100 & 75 & 100 & & \\
\hline
\end{tabular}

Hasil penelitian ini tidak jauh berbeda yang dilakukan oleh Trisnawati (2013), Hasil perhitungan OR menunjukkan seseorang yang obesitas mempunyai risiko untuk menderita diabetes. Kelompok dengan risiko diabetes terbesar adalah kelompok obesitas, dengan odds 7,14 kali lebih besar dibandingkan dengan kelompok IMT normal.

Adanya pengaruh IMT terhadap diabetes melitus ini disebabkan oleh kurangnya aktivitas fisik serta tingginya konsumsi karbohidrat, protein dan lemak yang merupakan faktor risiko dari obesitas. Hal tersebut menyebabkan meningkatnya Asam Lemak atau Free Fatty Acid (FFA) dalam sel. Peningkatan FFA ini akan menurunkan translokasi transporter glukosa ke membrane plasma, dan menyebabkan terjadinya resistensi insulin pada jaringan otot dan adipose (Teixeria-Lemos, 2011).
Masyarakat pesisir memiliki ketergantungan yang kuat terhadap lingkungan pesisir. Baik dan buruknya lingkungan pesisir akan berdampak secara langsung terhadap kehidupan mereka. Hal ini terkait dengan sumber daya perikanan yang ada seperti ikan tuna, lajang, cumi cumi, udang dan sebagainya. Hal ini juga sangat mempengaruhi peningkatan fraksi lipid yang diakibatkan dari konsumsi makanan - makanan yang mengandung kolesterol yang tinggi. Pada masyarakat pesisir juga memiliki kecenderungan untuk terbuka akan suatu hal yang baru, menyebabkan banyaknya pengaruh dari luar yang dapat mengakibatkan berubahnya pola makan dan aktivitas pada masyarakat pesisir, seperti bagi mereka yang tinggal dengan daerah perkotaan akan sering mengonsumsi makanan-makanan cepat saji dan berkalori tinggi, kemudian dengan terjadinya era modernisasi menyebabkan 
kemudahan dalam mengakses segala hal sehingga aktivitas seseorang akan berkurang dan menyebabkan penimbunan lemak yang banyak. Aktivitas masyarakat di daerah pesisir Kota Kendari cukup baik, dilihat dari kuesioner yang hampir semua berolahraga secara rutin sekali seminggu. Mereka mengikuti senam prolanis dari puskesmas yang diadakan rutin di setiap minggunya, hanya sedikit yang tidak mengikuti senam.

Simpanan asam lemak dalam bentuk senyawa kimia berupa triasilgliserol yang terdapat di dalam selsel adiposit dapat melindungi tubuh dari efek toksik asam lemak. Asam lemak dalam bentuk bebas dapat bersirkulasi dalam pembuluh darah ke seluruh tubuh dan menimbulkan stres oksidatif yang kita kenal dengan lipotoksisitas. Timbulnya efek lipotoksisitas yang disebabkan sejumlah asam lemak bebas yang dilepaskan triasilgliserol dalam upaya kompensasi penghancuran simpanan lemak yang berlebihan berpengaruh terhadap jaringan adiposa maupun non-adiposa, serta berperan pada patofisiologi penyakit di berbagai organ seperti hati dan pankreas. Pelepasan asam lemak bebas dari triasilgliserol yang berlebihan ini juga dapat menghambat sintesis lemak dan menurunkan bersihan triasilgliserol. Hal ini dapat meningkatkan kecenderungan hipertrigliseridemia. Pelepasan asam lemak bebas oleh lipoprotein lipase endotel dari trigliserida yang meningkat dalam peningkatan lipoprotein $\beta$ menyebabkan lipotoksisitas yang juga mengganggu fungsi reseptor insulin. Konsekuensi resistensi insulin adalah hiperglikemia, yang dikompensasi dengan sintesis glukosa dari hati (glukoneogenesis), yang justru ikut memperberat hiperglikemia. Asam lemak bebas juga ikut berkontribusi pada hiperglikemia dengan menurunkan penggunaan glukosa dari otot yang terstimulasi insulin. Lipotoksisitas akibat kelebihan asam lemak bebas juga menurunkan sekresi insulin dari sel $\beta$ pankreas, yang akhirnya sel $\beta$ akan mengalami kelelahan (Guyton, 2008).

\section{b. Hubungan riwayat keluarga dengan kejadian DM tipe-2 di daerah pesisir Kota Kendari}

Hasil pengolahan data yang dilakukan dengan uji Chi-Square menunjukkan bahwa terdapat hubungan antara riwayat keluarga dengan kejadian DM tipe-2 di daerah pesisir Kota Kendari, dilihat dari perolehan nilai $\mathrm{p}=0.0300$. Nilai OR dari penelitian ini sebesar 2,800 yang memiliki arti bahwa orang dengan riwayat keluarga DM tipe-2 memiliki risiko 2,8 kali lebih besar menderita penyakit DM tipe-2 dibandingkan dengan orang yang tidak memiliki riwayat keluarga. 
Hasil penelitian ini sejalan dengan yang dilakukan oleh Wicaksono (2011) pada 30 pasien rawat jalan di Poliklinik Penyakit Dalam RSUP Dr. Kariadi Semarang, dimana riwayat keluarga menderita DM merupakan faktor risiko terjadinya DM Tipe 2 yang bermakna secara statistik dan memiliki pengaruh terhadap kejadian DM Tipe 2 sebesar 75\%. Hasil ini juga sejalan dengan penelitian yang dilakukan oleh Kekenusa (2014) mengatakan bahwa terdapat hubungan antara riwayat keluarga menderita DM dengan kejadian DM Tipe $2(\mathrm{p}=0,000)$ dengan nilai Odds Ratio sebesar 4,7. Hal ini berarti bahwa orang yang memiliki riwayat keluarga menderita DM, berisiko 5 kali lebih besar terkena DM Tipe 2 dibandingkan dengan orang yang tidak memiliki riwayat keluarga menderita DM.

Risiko menderita DM bila salah satu orang tuanya menderita DM adalah sebesar 15\%. Jika kedua orang tua memiliki DM maka risiko untuk menderita DM adalah 75\% (Diabetes UK, 2010). Risiko untuk mendapatkan DM dari ibu lebih besar 10-30\% dari pada ayah dengan DM. Hal ini dikarenakan penurunan gen sewaktu dalam kandungan lebih besar dari ibu. Jika saudara kandung menderita DM maka risiko untuk menderita DM adalah 10\% dan 90\% jika yang menderita adalah saudara kembar identik (Diabetes UK, 2010). Bagi masyarakat yang memiliki keluarga yang menderita DM, harus segera memeriksa kadar gula darahnya karena risiko menderita DM besar.

DM tipe-2 berasal dari interaksi genetik dan berbagai faktor mental. Penyakit ini sudah lama dianggap berhubungan dengan agregasi familial. Penelitian di Jepang yang melibatkan 359 penderita DM tipe 2 dari 159 keluarga, mendukung bahwa penyakit ini berhubungan dengan kromosom 3q, 15q, dan 20q, serta mengidentifikasi 2 loci potensial, yaitu $7 \mathrm{p}$ dan $11 \mathrm{p}$ yang mungkin merupakan risiko genetik bagi DM tipe-2 pada masyarakat jepang. Dalam penelitian ini, orang yang memiliki riwayat keluarga menderita DM lebih berisiko daripada orang yang tidak memiliki riwayat keluarga menderita DM. Hal ini selaras dengan penelitianpenelitian sebelumnya yang menunjukkan terjadinya DM tipe-2 akan meningkat dua sampai enam kali lipat jika orang tua atau saudara kandung mengalami penyakit ini (Handayani, 2003).

\section{c. Hubungan IMT dan riwayat keluarga dengan kejadian DM tipe- \\ 2 di daerah pesisir Kota Kendari}

Hasil pengolahan data yang dilakukan menujukkan bahwa terdapat hubungan antara IMT dan riwayat keluarga dengan kejadian DM tipe-2 di daerah pesisir Kota Kendari, dilihat dari 
perolehan hasil uji Chi-Square yang dilakukan dengan nilai $\mathrm{p}=0.000$. Nilai $\mathrm{OR}$ dari penelitian ini sebesar 14,571 yang memiliki arti bahwa orang dengan IMT lebih dan riwayat keluarga DM tipe-2 memiliki risiko 14,571 kali lebih besar menderita penyakit DM tipe-2 dibandingkan dengan orang yang tidak memiliki riwayat keluarga DM tipe-2.

Berdasarkan penelitian ini, ditemukan bahwa semakin banyak faktor risiko yang dimiliki seseorang, maka risiko untuk menderita DM tipe-2 akan berkali lipat lebih besar. Oleh karena itu, untuk mencegah terjadinya DM tipe-2 dibutuhkan pengurangan dan pengendalian dari faktor risiko yang dimiliki.

\section{KESIMPULAN}

Terdapat hubungan antara IMT dengan kejadian DM tipe-2 di daerah pesisir Kota Kendari, dilihat dari perolehan nilai $\mathrm{p}=0,000$. Terdapat hubungan antara riwayat keluarga dengan kejadian DM tipe-2 di daerah pesisir Kota Kendari, dilihat dari perolehan nilai $\mathrm{p}=0.0300$. Terdapat hubungan antara IMT dan riwayat keluarga dengan kejadian DM tipe-2 di daerah pesisir Kota Kendari, dilihat dari perolehan nilai $\mathrm{p}=0,000$.

\section{SARAN}

Bagi peneliti yang ingin melanjutkan penelitian ini hendaknya melatih keterampilan lebih banyak untuk meningkatkan kebersihan dalam pengerjaan dan meningkatkan dalam sumber acuan. Bagi petugas kesehatan hendaknya bisa melakukan pemeriksaan secara genetik untuk mengenali faktor risiko kejadian DM tipe-2 dengan lebih akurat. Bagi masyarakat hendaknya memeriksakan diri masing-masing untuk bisa mengenali faktor risiko kejadian DM tipe-2 sehingga dapat melakukan pencegahan sedini mungkin.

\section{DAFTAR PUSTAKA}

American Diabetic Association, 2014. Diagnostic and Classification of Diabetes Mellitus. Diabetes Care. 7: 82-90.

Diabetes UK. 2010. Diabetes in the UK: Key Statistics on Diabates.

Dinas Kesehatan Kota Kendari. 2016. Data Jumlah Penderita Diabetes Melitus di Kota Kendari. Dinas Kesehatan Kota Kendari.

Dinas Kesehatan Provinsi Sulawesi Tenggara, 2015. Profil Kesehatan Sulawesi Tenggara Tahun 2015. Dinas Kesehatan Provinsi Sulawesi Tenggara, Kendari.

Guyton, A.C., Hall, J.E. 2008. Buku Ajar Fisiologi Kedokteran. Jakarta: EGC.

Handayani SA. 2003. Faktor-faktor resiko diabetes melitus tipe-2 di semarang dan sekitarnya [Thesis]. Semarang: Universitas Diponegoro.

International Diabetes Federation. 2015. IDF DIABETES ATLAS Seventh Edition 2015. Karakas Print.

Justitia, N.L., 2012. Dalam skripsi: Hubungan Obesitas dengan Peningkatan Kadar Gula Darah 
Pada Guru-Guru SMP Negeri 3 Medan. Fakultas Kedokteran Universitas Sumatera Utara Medan.

Kekenusa, J.S., Ratag, B.T., Wuwungan, G. 2014. Analisis Hubungan Antara Umur Dan Riwayat Keluarga Menderita DM dengan Kejadian Penyakit Dm Tipe 2 Pada Pasien Rawat Jalan Di Poliklinik Penyakit Dalam Blu Rsup Prof. Dr. R.D Kandou Manado. Manado: Universitas Sam Ratulangi.

Kommoju, Uma J. dan Reddy, Battini M., 2011. Genetic Etiology of Type 2 Diabetes Mellitus: A Review. Int J Diabetes Dev Ctries. 31(2):51-64.

Riset Kesehatan Dasar, 2013. Penyajian Pokok-Pokok Hasil Riset Kesehatan Dasar 2013. Indonesia: Kementrian Kesehatan RI.

Teixeria-Lemos, et.al., 2011. Regular physical exercise training assists in preventing type 2 diabetes development: focus on its antioxidant and anti-inflammantory properties. Biomed Central Cardiovascular Diabetology 10: 115.

Trisnawati, S. H., Setyogoro, S., 2013. Faktor Risiko Kejadian Diabetes Melitus Tipe II Di Puskesmas Kecamatan Cengkareng Jakarta Barat Tahun 2012. Program Studi Kesehatan Masyarakat Sekolah Tinggi Ilmu Kesehatan MH. Thamrin Jakarta.

Wicaksono, R. 2011. Faktor-Faktor yang Berhubungan dengan Kejadia Diabetes Melitus Tipe 2 (Skripsi). Universitas Diponegoro, Semarang.

World Health Organization, 2006. Definition and diagnosis of diabetes mellitus and intermediate hyperglycemia: Report of WHO/IDF Consultation, Geneva. 